\title{
Assessment of Cybersecurity Effectiveness in Serving Maqasid Al-Shariah
}

\author{
Yassir Izzadin ${ }^{1}$, Jamaludin Ibrahim ${ }^{2}$ \\ ${ }^{1,2}$ Department of Information Systems, International Islamic University Malaysia, IIUM
}

\begin{abstract}
This paper evaluates cybersecurity effectiveness in preserving Maqasid al-Shariah most valuable assets through measuring its ability to protect them from modern cyber threats and cyber-attacks. In order to perform this evaluation we proposed a model that uses Maqasid al-Shariah to decide on the priorities and assets that should be safeguarded and protected from cyber-attacks.
\end{abstract}

Keywords: Maqasid Shariah Cybersecurity; Islam and Cybersecurity; Islam and Cyberattacks; Islam and Cyber threats; Maqasid Shariah; Cybersecurity capability maturity model; C2M2;MS-C2M2; Cybersecurity;

\section{Introduction}

Maqasid al-Shariahare the main goals and objectives of Islamic Shariah, their aim is to promote the well-being of people by protecting their five most important assets which are their faith, self, intellect, posterity and wealth.

These assets which Maqasid al-Shariah strives to protect like any other asset are exposed to threats and danger, and if not well secured can lead to great damage for the Muslim as an individual and the society as a whole.

One of the major threats which those five necessities can be exposed to in the modern era are known as cybercrimes. A cybercrime can be defined as a crime committed in the cyber space or a crime committed with the assistance of the internet. (Sindhu, 2012)

For this reason aroused the need to secure the cyber space through cybersecurity. Cybersecurity can be defined as the actions and measures both technical and non-technical, with the express purpose of protecting computers, networks, software, data and other related digital technologies from all threats.(Lee, 2016)

In this paper our target is to assess the cybersecurity degree of effectiveness in serving Maqasid al-Shariahby preserving its most valuable assets and securing them from cyber threats and cyber-attacks.

\section{Literature Review}

\section{A. Related Work}

There have been several studies that measured cybersecurity and its efficiency to mankind. These studies primary focus is about providing protection to the cyber world.

"A cybersecurity capability maturity model based on Maqasid al-Shariah(MS-C2M2)" tries to understand the exposure of assets (As defined by Maqasid al-Shariah) to cyber threats, and then proposes a framework that measures cybersecurity protective capability to preserve the assets related to Maqasid al-Shariahfrom cyber threats.
"Security metrics a practical framework for measuring security and protecting data" proposes a framework that helps to situate security and security metrics within the context of business process improvement.

\section{B. Cybersecurity capability maturity model}

A maturity model is a conceptual framework that comprises a collection of best practices that help organizations to improve their processes in a particular area of interest. (Turetken, 2016)

The United States department of energy in collaboration with Carnegie Mellon University developed the Cyber security Capability Maturity Model, which is a voluntary evaluation process utilizing industry-accepted cyber security practices that can be used to measure the maturity of an organization's cybersecurity capabilities.

We selected the C2M2 as our method of evaluation due to its efficiency, flexibility and maturity. In this paper we will incorporate Maqasid al-Shariahto a simplified version of C2M2 to create an MS-C2M2 (Maqasid al-Shariah Cybersecurity Capability Maturity Model) framework to measure cybersecurity maturity within the scope of Maqasid al-Shariah.

\section{Maqasid al-Shariah}

Maqasid al-Shariahhave been either directly stated in the Quran and the Sunnah or inferred from these by a number of scholars, all of these address the reason for existence of Shariah which is to serve the interests (Jalb al-masalih) of all human beings and to save them from harm (daf al-mafasid).

Imam Abu-Hamid al-Ghazali classified the maqasid into five major categories stating that: the very objective of the Shariah is to promote the well-being of the people, which lies in safeguarding their faith (deen), their self (nafs), their intellect (aql), their posterity (nasl) and their wealth (mal).whatever ensures the safeguard of these five serves public interest and is desirable, and whatever hurts them is against public interest and its removal is desirable. (Chapra, 2010) 


\title{
International Journal of Science and Research (IJSR) \\ ISSN (Online): 2319-7064
}

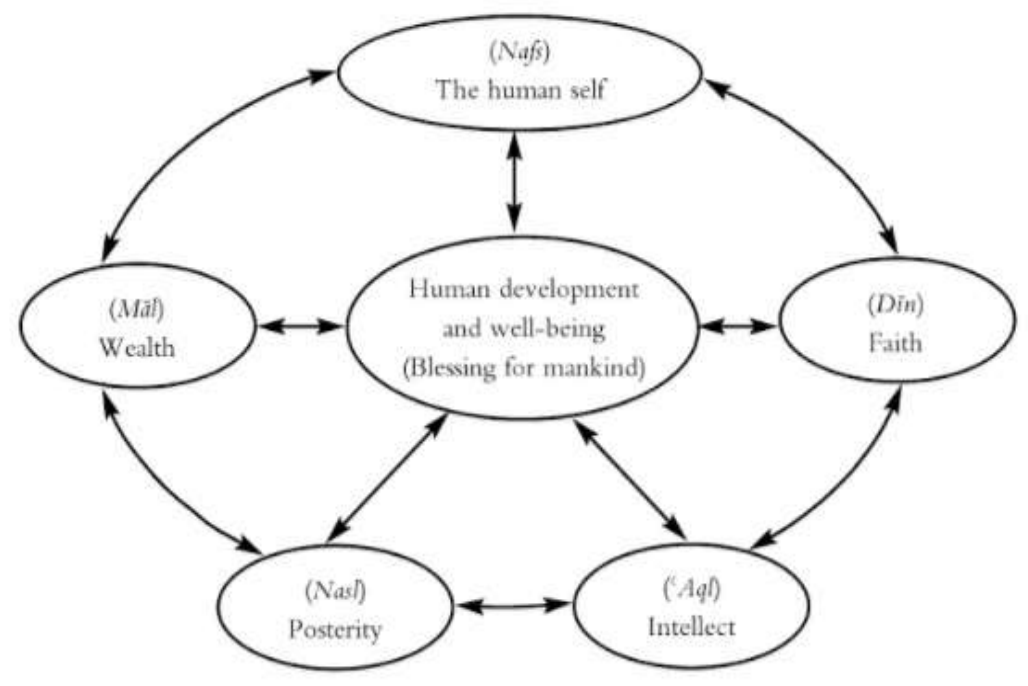

Figure 1: Maqasid al-Shariah: Human development and well-being to be realized by ensuring the enrichment of the following five ingredients for every individual (Chapra, 2010)

\section{MS-C2M2 Conceptual framework}

The concept of MS-C2M2 at the identification stage is to identify assets and relevant sub assets, threats and criticalities. This is illustrated in figure 2 :

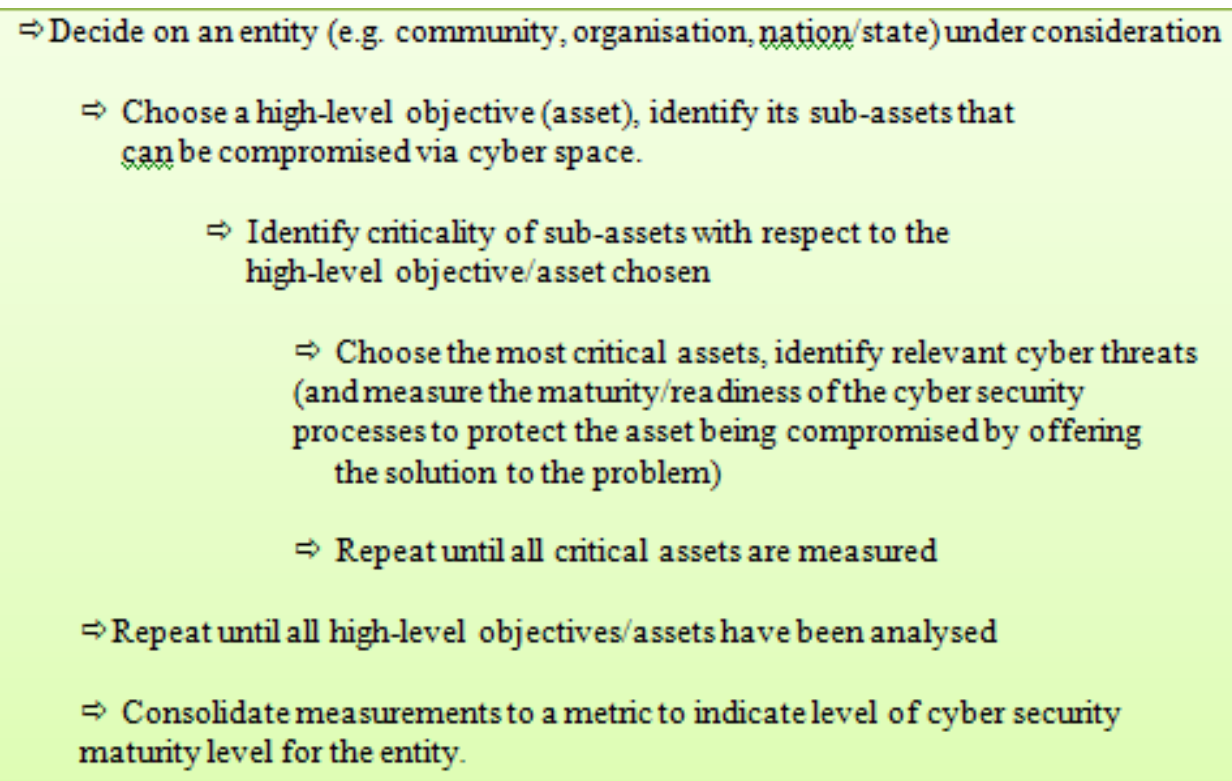

Figure 2: Steps of the MS-C2M2 framework at the Identification Phase (Jamaludin Ibrahim, 2015)

The table that follows shows the mapping of possible cyber threats at the asset identification phase:

Table 1: MS-C2M2 Cyber Threats Mapping (at Asset Identification Phase) (Jamaludin Ibrahim, 2015)

\begin{tabular}{|c|c|c|c|}
\hline $\begin{array}{c}\text { Maqasidal- } \\
\text { Shariah } \\
\text { Assets }\end{array}$ & $\begin{array}{c}\text { Examples of Sub-Assets-that } \\
\text { support the asset/objective }\end{array}$ & $\begin{array}{c}\text { Examples of Critical Sub-Assets- } \\
\text { critical to the asset/objective }\end{array}$ & $\begin{array}{c}\text { Cyber security Threats-that will exploit vulnerability of the } \\
\text { Critical Sub-Assets }\end{array}$ \\
\hline Deen-Faith & $\begin{array}{c}\text { Access to guided principles, } \\
\text { knowledge, examples and } \\
\text { scholars }\end{array}$ & $\begin{array}{c}\text { Access to guided principles, } \\
\text { knowledge, examples and scholars }\end{array}$ & $\begin{array}{c}\text { Influence by misguided/distorted/addictive online lifestyle } \\
\text { e.g. pornography, stalking/voyeurism, gambling }\end{array}$ \\
\cline { 2 - 4 } & $\begin{array}{c}\text { Faith Conducive } \\
\text { Environment }\end{array}$ & $\begin{array}{c}\text { Faith Conducive Environment e.g. } \\
\text { faith building/strengthening, } \\
\text { enjoining good forbidding evil, } \\
\text { convey message of Islam to all }\end{array}$ & $\begin{array}{c}\text { Online influence by unhealthy/stealthily ideologies norms, } \\
\text { practices and environment e.g. satanic worship, subliminal } \\
\text { suggestion, anti-religion/faith, deviant teachings, non- } \\
\text { Islamic/western liberalism }\end{array}$ \\
\cline { 2 - 5 } & & $\begin{array}{c}\text { Strong society, family and peer } \\
\text { support structure }\end{array}$ & Strong society, family and peer support structure \\
\hline
\end{tabular}

\section{Volume 6 Issue 12, December 2017}

\author{
www.ijsr.net
}

Licensed Under Creative Commons Attribution CC BY 


\section{International Journal of Science and Research (IJSR) ISSN (Online): 2319-7064}

Index Copernicus Value (2016): 79.57 | Impact Factor (2015): 6.391

\begin{tabular}{|c|c|c|c|}
\hline & & Healthy Socialization & Healthy Socialization \\
\hline & $\begin{array}{c}\text { Security of } \\
\text { community/national security } \\
\text { in order to defend faith }\end{array}$ & \begin{tabular}{|c|} 
Critical infrastructure related to \\
security(e.g. power, food \& water, \\
weather, transportation, \\
financial/monetary systems, \\
communications)
\end{tabular} & $\begin{array}{r}\text { Cyber attacks such as cyber warfare, and cyber espionage } \\
\text { that are driven by economic, financial, military or political } \\
\text { agenda }\end{array}$ \\
\hline \multirow[t]{5}{*}{ Nafs-Life } & \multirow[t]{3}{*}{$\begin{array}{l}\text { Health, Foodand } \\
\text { Environment }\end{array}$} & $\begin{array}{c}\text { Healthy lifestyle and medical } \\
\text { treatment }\end{array}$ & $\begin{array}{c}\text { Attack to online systems that health and medical related } \\
\text { information e.g. hospital systems Misguided online health } \\
\text { advices Addiction to online activities e.g. social } \\
\text { networking }\end{array}$ \\
\hline & & Food security & $\begin{array}{c}\text { Threats to online systems related to agriculture, food } \\
\text { production and food distribution }\end{array}$ \\
\hline & & Physical Conducive Environment & $\begin{array}{c}\text { Attack of online systems related to environment protection, } \\
\text { pollution monitoring, weather }\end{array}$ \\
\hline & $\begin{array}{l}\text { Strong society, family and } \\
\text { peer support structure }\end{array}$ & $\begin{array}{c}\text { Strong society, family and peer } \\
\text { support structure }\end{array}$ & $\begin{array}{c}\text { Society's attachment to } 2^{\text {nd }} \text { life, Lost touch of reality, } \\
\text { natural and physical environment }\end{array}$ \\
\hline & *Personal Safety & $\begin{array}{c}\text { * Ensuring safety on air flights, } \\
\text { space crafts, trains etc... }\end{array}$ & $\begin{array}{l}\text { Cyber attacks on in flight displays to change information } \\
\text { such as altitude and location, control the cabin lightening } \\
\text { and hack into the announcement system, Lost touch of } \\
\text { reality, natural and physical environment }\end{array}$ \\
\hline \multirow[t]{3}{*}{ 'Aql-Intellect } & \multirow{4}{*}{\begin{tabular}{|c|} 
Ability to: \\
Read, Reason, Formulate \\
meaning (which involves \\
Judgement, Discrimination, \\
Clarification), Communicate, \\
Teaching \&Learning
\end{tabular}} & Ability to reason & Influence by dissemination of distorted information \\
\hline & & Ability to formulate meaning & Influence by dissemination of distorted information \\
\hline & & Ability to communicate & $\begin{array}{l}\text { Attacks that deny accessibility of communicating the right } \\
\text { information or ideology, Distributed Denial of Services } \\
\text { (DDoS) }\end{array}$ \\
\hline $\begin{array}{l}\text { 'Aql-Intellect } \\
\text { (Cont. })\end{array}$ & & \begin{tabular}{|c|}
$\begin{array}{c}\text { Promotion of intellectual culture } \\
\text { and love of knowledge }\end{array}$ \\
\end{tabular} & $\begin{array}{c}\text { Glorification of hedonism through cyber channels and } \\
\text { media }\end{array}$ \\
\hline \multirow{5}{*}{$\begin{array}{l}\text { Nasl-Progeny } \\
\text { Ensuring good } \\
\text { family lineage }\end{array}$} & Marriage and family building & $\begin{array}{c}\text { Marriage, birth and death } \\
\text { registration }\end{array}$ & $\begin{array}{c}\text { Attacks to systems that manage marriage, births and death } \\
\text { records }\end{array}$ \\
\hline & $\begin{array}{l}\text { Strong society, family and } \\
\text { peer support structure }\end{array}$ & $\begin{array}{l}\text { Strong society, family and peer } \\
\text { support structure }\end{array}$ & $\begin{array}{l}\text { Influence by misguided/distorted/addictive online } \\
\text { examples e.g. Pornography, Stalking/Voyeurism, } \\
\text { Gambling }\end{array}$ \\
\hline & $\begin{array}{c}\text { Choice of compatible\& } \\
\text { healthy marriage partner } \\
\text { (from opposite sex) }\end{array}$ & $\begin{array}{l}\text { Choice of compatible\& healthy } \\
\text { marriage partner (from opposite } \\
\text { sex) }\end{array}$ & $\begin{array}{l}\text { Influence by unhealthy/stealthily online norms, practices } \\
\text { and environment e.g. online dating, random partner, } \\
\text { hedonistic criteria, glamor, anti-family friendly suggestions }\end{array}$ \\
\hline & $\begin{array}{l}\text { Family Friendly/Conducive } \\
\text { Environment }\end{array}$ & $\begin{array}{l}\text { Family Friendly/Conducive } \\
\text { Environment e.g. simple \& } \\
\text { affordable marriage process }\end{array}$ & $\begin{array}{l}\text { Family data privacy compromised by giving full trust to } \\
\text { social networking sites }\end{array}$ \\
\hline & \begin{tabular}{|c|}
$\begin{array}{c}\text { Healthy family oriented } \\
\text { lifestyle }\end{array}$ \\
\end{tabular} & $\begin{array}{l}\text { Healthy relation among family } \\
\text { members and relatives }\end{array}$ & Promotion of individualistic lifestyle \\
\hline \multirow[t]{5}{*}{ Mal-Wealth } & $\begin{array}{l}\text { Financial and tangible wealth } \\
\text { assets }\end{array}$ & Financial wealth and assets & $\begin{array}{c}\text { Threats to information systems related to banking, } \\
\text { financial and wealth assets management leading to theft, } \\
\text { fraud, scams }\end{array}$ \\
\hline & Human \&intellectual capital & Human and intellectual capital & $\begin{array}{l}\text { Ideology that misguide or corrupt ones' principles of life, } \\
\text { Cyber espionage, abuse of intellectual capability for the } \\
\text { wrong purpose. The loss of the international intellectual } \\
\text { property regime as an effective system to stimulate } \\
\text { innovation and investment. }\end{array}$ \\
\hline & Critical infrastructure & $\begin{array}{c}\text { Critical infrastructure that } \\
\text { supports: } \\
\text { Power, Food\& water, } \\
\text { Transportation, Communication, } \\
\text { Financial system, Education } \\
\text { system, Health system }\end{array}$ & $\begin{array}{l}\text { Cyber attacks such as cyber warfare, and cyber espionage } \\
\text { that are driven by economic, financial, military or political } \\
\text { agenda. Single-point system vulnerabilities trigger } \\
\text { cascading failure of the critical information infrastructure } \\
\text { and networks. }\end{array}$ \\
\hline & $\begin{array}{l}\text { Strategic digital resources, } \\
\text { intellectual propertyand } \\
\text { intangible wealth assets }\end{array}$ & $\begin{array}{c}\text { Strategic digital resources that } \\
\text { support the socio-economic } \\
\text { development and well being of a } \\
\text { nation. Data on citizen, consumer, } \\
\text { industry\& provider. } \\
\text { Patents, copyrights, trademarks, } \\
\text { reputation\& brand, trade secrets, } \\
\text { processes, partner network }\end{array}$ & $\begin{array}{c}\text { Criminal or wrongful exploitation of public \& private data } \\
\text { of unprecedented scale. Hijacked/stolen digital resources, } \\
\text { IP theft } \\
\text { Deliberately provocative, misleading or incomplete } \\
\text { information disseminates rapidly and extensively with } \\
\text { dangerous consequences affecting socio- economic } \\
\text { development and well being of a nation } \\
\text { *Ransomware: Locking data on a victim's computer by } \\
\text { encryption and demanding payment before ransomed data } \\
\text { is decrypted }\end{array}$ \\
\hline & Natural resources & $\begin{array}{c}\text { Land, forest, oil and gas, minerals, } \\
\text { etc. }\end{array}$ & $\begin{array}{c}\text { Threats to systems of government authorities / } \\
\text { organisations that manage and control natural resources. }\end{array}$ \\
\hline
\end{tabular}

* This is my personal addition to the table

Volume 6 Issue 12, December 2017 www.ijsr.net

Licensed Under Creative Commons Attribution CC BY 


\section{Analysis and Evaluation}

Maqasid al-Shariahcritical assets are exposed to several cyber threats which if not protected against could lead to disastrous results on the individual level and on the society level as a whole. Cybersecurity can perform a good job in protecting these critical assets from the threats of the cyber world, however these cyber threats continue evolving and new forms of cyber threats always appear, so cybersecurity needs to be improved continuously to keep up with this fast paced challenging cyber world.

\section{Conclusion}

This paper evaluates the effectiveness of cyber security in serving Maqasid al-Shariahby measuring its potential to protect the five critical assets that Shariah seeks to preserve.

Maqasid al-Shariahis used to create a framework for cybersecurity capability maturity model. This model measures the effectiveness of cybersecurity within the goals and objectives of Maqasid al-Shariah.

\section{References}

[1] Sindhu, K. K., ～\& Meshram, B. B. (2012). Digital Forensic Investigation Tools and Procedures. International Journal of Computer Network and Information Security, 4(4), 39-48. doi:10.5815/ijcnis.2012.04.05

[2] Lee, I. (2016). Encyclopedia of e-commerce development, implementation, and management: Volume 1. Hershey, PA: Business Science Reference.

[3] Turetken, O., Stojanov, I., \& Trienekens, J. J. (2016). Assessing the adoption level of scaled agile development: a maturity model for Scaled Agile Framework. Journal of Software: Evolution and Process, 29(6), e1796. doi:10.1002/smr.1796

[4] Chapra, M. U. (2010). The Islamic vision of development in the light of Maqasid al-Shariahh. India: Islamic Fiqh Academy.

[5] Jamaludin Ibrahim, Aznan Zuhid Saidin, Abdul Rahman Ahmad Dahlan, Normaziah Abdul Aziz, Mohamed Ridza Wahiddin, Rahmah Ahmad H. Osman. (n.d.). A Cybersecurity Capability Maturity Model Based on Maqasid Shariah. 2015.

[6] United States of America Department of Energy, Office of Electricity Delivery and Energy Reliability,Cybersecurity CapabilityMaturity Model (C2M2). Retrieved 13October 2017 from: https://energy.gov/sites/prod/files/2014/02/f7/C2M2-

FAQs.pdf 